\title{
ВПЛИВ ЗБАГАЧЕНОЇ ТРОМБОЦИТАМИ ПЛАЗМИ КРОВІ НА СТАН СИСТЕМИ ПРОТЕЇНАЗИ/ІНГІБІТОРИ ПРОТЕЇНАЗ ПРИ ТРАВМАТИЧНОМУ УРАЖЕННІ М'ЯЗІВ
}

\section{○В. Г. Дживак, І. М. Кліщ}

Тернопільський начіональний медичний університет імені І. Я. Горбачевського МОЗ України

РЕзЮМЕ. Порушення протеїназо-інгібіторної системи відіграють важливу роль у патогенезі багатьох патологічних процесів. Надмірний протеоліз може спричинити розвиток цілої низки патологічних станів, що супроводжуються виникненням деструктивних, запальних та імунних реакцій.

Мета - встановити особливості функціонування системи протеїнази/інгібітори протеїназ за умов травматичного ураження м' язів в експерименті і з' ясувати вплив збагаченої тромбоцитами плазми крові на стан протеазно/антипротеазної активності.

Матеріал і методи. Травму м'язів стегна моделювали за розробленою методикою в умовах тіопентало-натрієвого знеболювання. Дослідні тварини були поділені на три групи: I - контроль (без змодельованої патології), II тварини з травматичним ураженням м'язів стегна без введення збагаченої тромбоцитами плазми крові, III - тварини з травматичним ураженням м'язів стегна та введенням збагаченої тромбоцитами плазми крові. Тварин на 1-шу, 7-му, 14-ту, 21-шу доби після моделювання травми виводили з експерименту. Приготування РRP відбувалося двоетапно. Було проаналізовано вплив корекції збагаченої тромбоцитами плазми крові на зміни активності системи протеолізу і показників антипротеазної системи в експерименті при травматичному ураженні м'язів тварин, яким проводилася корекція збагаченою тромбоцитами плазмою крові. Забір біологічного матеріалу проводили на 1-шу, 7-му, 14-ту, 21-шу доби після травматичного ураження м'язів. Для дослідження активності протеїназної системи та вмісту інгібіторів протеолізу використані спектрофотометричні методи.

Результати. Досліджено вплив збагаченої тромбоцитами плазми крові (PRP) на показники протеїназо-інгібіторної системи крові. У тварин з м' язовою травмою встановлено підвищення протеолітичної активності крові на тлі незначного зростання вмісту $a_{1}$-інгібітора протеаз та $a_{2}$-макроглобуліну, що вказує на недостатнє посилення антипротеолітичного потенціалу для стримування розвитку деструкції. У тварин, яким після нанесення травми вводили PRP, відбувалося достовірне зростання протеолітичної активності крові на тлі більш виразного збільшення антипротеазної активності. Це призводить до зниження індексу протеолізу.

Висновок. При механічній травмі м' язів спостерігається інтенсивне зростання протеолітичної активності крові на тлі незначного підвищення антипротеазної активності. Застосування PRP як засобу корекції супроводжується зростанням антипротеазної активності та зниженням індексу протеолізу.

Ключові СловА: механічна травма м'язів; плазма, збагачена тромбоцитами; протеїназо-інгібіторна система.

Вступ. Порушення протеїназо-інгібіторної системи відіграють важливу роль у патогенезі багатьох патологічних станів [1, 2]. Реакції обмеженого протеолізу мають місце у процесі утворення активних форм ензимів з неактивних попередників, а також у синтезі гормонів, структурних білків, ряду білків плазми крові, утворенні та інактивації біоактивних пептидів (кініни, нейропептиди), що беруть участь в регуляції судинного тонусу, процесів мікроциркуляції, функції мозку тощо $[2,3]$. Різноманітний спектр фізіологічної дії протеїназ, їх висока активність стосовно білкових субстратів зумовлюють складність механізмів регуляції цих процесів в організмі [3]. Серед факторів, що визначають біологічну активність протеїназ, можна назвати концентрацію ферменту і субстрату, рH, іонну силу і температуру. Проте однією з найважливіших ланок контролю за протеолізом $\epsilon$ вміст у крові та тканинах специфічних білків та інгібіторів протеолітичних ферментів, зокрема $a_{1}$-інгібітора протеїназ, $\mathrm{a}_{2}$-макроглобуліну, антитромбіну III, $\mathrm{a}_{2}$-антиплазміну, $\mathrm{a}_{1}$-антихімотрипсину, які утворюють комплекси з протеїназами, знижуючи при цьому їх активність $[3,4]$.
За фізіологічних умов активність протеолітичних ферментів урівноважена із рівнем інгібіторів протеїназ. При критичних станах відбувається порушення динамічної рівноваги між протеазами та їх інгібіторами. Збільшення кількості та активності ферментів протеолізу тканинного походження веде до «протеазного вибуху», у зв' язку з чим гіперактивуються згортальна, фібринолітична, калікреїнкінінова, ренін-ангіотензин-альдостеронова системи і комплемент. Викликані зміни зумовлюють розвиток деструктивних і запальних змін у всьому організмі $[5,6]$.

За дії різних патогенних чинників спостерігається значне підвищення активності протеолітичних ферментів, і вони з фактора регуляції перетворюються на чинник пошкодження $[2,8]$. Однією з причин, які зумовлюють цю трансформацію, $\epsilon$ зниження активності ендогенних інгібіторів протеїназ і підвищення проникності лізосомальних мембран [9].

Зростання травматизму в усьому світі залишається однією з актуальних соціально-економічних проблем сучасності $[10,11]$. В Україні щороку 
Огляди літератури, оригінальні дослідження, погляд на проблему, випадок з практики, короткі повідомлення травми різного ступеня тяжкості отримує близько $10 \%$ населення. Смертність від нещасних випадків і травм в Україні зростає в середньому на 1 \% щорічно [12]. За даними ВООЗ, серед причин смертності травми посідають третє, а серед населення до 40 років - перше місце. Незважаючи на те, що потерпілі з політравмою складають 8-10\% від усіх, що потрапляють на стаціонарне лікування, саме на них припадає до 70 \% летальних випадків [13]. При цьому смертність від нещасних випадків і травм постійно зростає - в середньому на $1 \%$ щорічно [14], що $\epsilon$ свідченням недостатньої ефективності надання медичної допомоги таким хворим.

Зважаючи на це, метою наших досліджень було встановлення особливостей функціонування системи протеїнази/інгібітори протеїназ за наявності м'язової травми.

Матеріал і методи дослідження. Експериментальне дослідження виконано на 92 нелінійних білих щурах масою 180-210 г, яких утримували на стандартному раціоні віварію Центральної науково-дослідної лабораторії. Тварин було поділено на 3 групи: контроль - 12 щурів - інтактні, перша дослідна група з травматичним ураженням м'язів стегна без введення PRP (40 щурів), друга дослідна група - з травматичним ураженням м'язів стегна та введенням PRP (40 щурів). Травму моделювали за розробленою методикою в умовах тіопентало-натрієвого знеболювання (40 мг/кг) згідно з конвенцією $[15,16]$. Робота була проведена на базі Центральної науково-дослідної лабораторії (свідоцтво про атестацію № 001/18 від 26 вересня 2018 року) та міжкафедральної навчально-дослідної лабораторії (свідоцтво про атестацію №132/17 видане 29 грудня 2017 року) Тернопільського національного медичного університету імені І. Я. Горбачевського МОЗ України.

При роботі з тваринами дотримувались правил поводження з експериментальними тваринами згідно з директивою Ради ЄC 2010/63/EU про дотримання постанов, законів, адміністративних положень Держав ЄС з питань захисту тварин, які використовуються для наукової мети [15-17].

Для дослідження використовували сироватку крові та гомогенат м'язів. Тварин виводили з експерименту під тіопенталовим наркозом на 1-шу, 7-му, 14-ту і 21-шу доби після нанесення травми.

Визначення загальної протеолітичної активності плазми крові проводили за лізисом азоальбуміну, азоказеїну і азоколу за допомогою набору реактивів "Simko Ltd» (Україна) за методом [2], який полягає в тому, що при інкубації білкових азосполук у присутності активаторів та інгібіторів протеолізу, які містяться у тканинах, відбувається лізис азоальбуміну (розпад низькомолекулярних протеїнів), азоказеїну (розпад високомолекулярних протеїнів) та азоколагену (колагеноліз), інтенсивність якого оцінювали за ступенем забарвлення інкубаційного середовища на спектрофотометрі СФ-46 при довжині хвилі 440 нм. Протеолітичну активність визначали в одиницях екстинкції на 1 мл плазми за 1 годину.

Визначення вмісту $\mathrm{a}_{2}$-макроглобуліну ( $\left.\mathrm{a}_{2}-\mathrm{M \Gamma}\right)$ у сироватці крові проводили методом, принцип якого полягає в тому, що $\mathrm{a}_{2}$-МГ утворює з трипсином активний комплекс, який $\epsilon$ нечутливим до дії інгібітора з бобів сої. Для виконання методики використовували трипсин ("Spofa», Чехія). Концент-

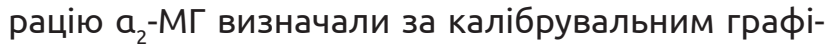
ком, в якому по осі абсцис відкладали кількість трипсину, а по осі ординат - оптичну щільність проб, в яких відбувся гідроліз N-бензоїл-DL-apгінін-пара-нітроаніліду (БАПНА) відповідною концентрацією трипсину. Концентрацію $a_{2}$-МГ виражали в г/л у сироватці крові [4].

Визначення вмісту $a_{1}$-інгібітора протеаз $\left(a_{1}-1 П\right)$ у сироватці крові проводили методом, що базується на здатності $a_{1}$-ІП сироватки крові пригнічувати гідроліз трипсином БАПНА. В той же час трипсин у комплексі з $\mathrm{a}_{2}$-МГ здатний розщеплювати БАПНА. Вміст $a_{1}-$ ІП визначали за різницею між відомою кількістю трипсину і кількістю ферменту, що залишився після його взаємодії з інгібіторами плазми. Вміст $\mathrm{a}_{1}-$ ІП визначали за калібрувальним графіком, в якому по осі абсцис відкладено кількість трипсину (1-10 мкг), а по осі ординат - оптичну щільність проб, в яких відбувся гідроліз БАПНА відповідною концентрацією трипсину. Вміст $a_{1}-$-ІП у сироватці крові виражали в мкмоль/л [8].

Розраховували індекс протеолізу (ІП), що відо6ражає напруженість або «керованість» протеолітичних процесів, як відношення ЗПА до сумарної інгібіторної ємності (сума активності $a_{1}-$ ІІ і $a_{2}$ МГ) [3].

Для приготування гомогенату м'язову тканину розтирали за допомогою гомогенізатора при $4^{\circ} \mathrm{C}$ і суспендували в 9 о6' ємах 0,25 М розчину цукрози з 0,001 М Na${ }_{2}$ ЕДТА, рН 7,4. Сполучнотканинні елементи, які залишились в середовищі, видаляли центрифугуванням (1000 о6/хв протягом 3 хв) при охолодженні. Надосадову частина гомогенату використовували для досліджень. Загальну активність катепсину D у гомогенаті м'язів визначали методом Дингла у модифікації [9]. Активність ферменту виражали в мкМ тирозину/(мг білкахгод).

Отримання збагаченої тромбоцитами плазми відбувалося у два етапи з дотриманням усіх правил стерильності. Кров білих щурів отримували шляхом пускання з серця у пробірку із антикоагулянтом у співвідношенні кров/антикоагулянт - 
Огляди літератури, оригінальні дослідження, погляд на проблему, випадок з практики, короткі повідомлення

9:1, та поміщали у лабораторну центрифугу LMC3000 «Biosan» (Латвія).

Перше центрифугування проводили впродовж 10 хвилин для осадження еритроцитів та лейкоцитів зі швидкістю 1600 о6./хв. Друге центрифугування було проведене зі швидкістю 2100 об./хв. протягом 10 хвилин.

Статистичну обробку цифрових даних здійснювали за допомогою програмного забезпечення «Excel» та «STATISTICA»з використанням параметричних і непараметричних методів оцінки отриманих даних. Для всіх показників розраховували значення середньої арифметичної вибірки (M), іï дисперсії і помилки середньої (m). Достовірність різниці значень між незалежними кількісними величинами визначали при нормальному розподілі за t-критерієм Стьюдента, в інших випадках - за допомогою U-критерію Манна-Уїтні (достовірними вважали відмінності при р<0,05).

Результати й обговорення. Показники протеолітичної активності сироватки крові у щурів, яким моделювали травму м'язів, були достовірно вищими, ніж у тварин без змодельованої патології. Так, лізис азоальбуміну на першу добу після нанесення травми був достовірно вищим від показника тварин без змодельованої патології у 7,6 раза. Аналогічні зміни були відмічені і стосовно лізису азоказеїну та азоколу. Зокрема, показник лізису азоказеїну у цей термін спостереження був у 10,3, а лізис азоколу - у 7,7 раза вищим, ніж у тварин, яким травми не моделювали. В обох випадках різниця між показниками була достовірною. На сьому добу показник лізису азоальбуміну дещо знизився, однак перевищував рівень тварин без змодельованої патології в 4,6 раза. Зміни показників лізису азоказеїну та азоколу мали аналогічну спрямованість і на 7-му добу від моменту нанесення травми складали відповідно 843,5 та 514,8 \% від показників тварин без змодельованої патології. До 14-ї доби показник лізису азоальбуміну залишався практично на тому ж рівні, що й у попередній термін спостереження, а показники азоказеїну та азоколу знижувались, однак все ж перевищували рівень тварин без змодельованої патології у 6,1 та 2,6 раза відповідно. До 21-ї доби усі показники, що характеризують стан протеолітичної активності сироватки крові, зменшувались, проте були достовірно вищими від норми. Так, лізис азоальбуміну склав 330,7 \%, азоказеїну - 329,1 \%, азоколу - 265,4 \% від аналогічних показників здорових тварин (табл. 1).

Застосування плазми крові, збагаченої тромбоцитами, супроводжувалось зменшенням протеолітичної активності сироватки крові. Лізис азоальбуміну на 1-у добу від моменту нанесення травми у тварин цієї групи перевищував рівень тварин без змодельованої патології в 5,8 раза, однак був на 30,5 \% меншим, ніж у тварин, яким моделювали травму, але корекції не проводили. Лізис азоказеїну також перевищував рівень здорових тварин у 8,9 раза, що, однак, на 16 \% менше, ніж у тварин без корекції. Аналогічну спрямованість мав також лізис азоколу - показник був 5,3 раза вищим, ніж у нормі, проте меншим від рівня тварин без змодельованої патології на 44,4 \%.

На сьому добу експерименту не спостерігалось нормалізації протеолітичної активності. 3окрема, лізис азоальбуміну був вищим від показника тварин без змодельованої патології в 3,9 раза та на 17,8 \% меншим, ніж аналогічний показник тварин без корекції. Показники лізису азоказеїну та азоколу за спрямованістю були майже аналогічними до показника азоальбуміну, однак в цифровому вимірі відрізнялися. Зокрема, показник азоказеїну перевищував норму у 7,1 раза, азоколу - у 2,7 раза, причому обидва показники були достовірно меншими, ніж у травмованих тварин, яким корекцію не проводили - на 18,8 та 93,9 \% відповідно.

Більш виразне зниження протеолітичної активності ми встановили на 14-ту добу експерименту. Лізис азоальбуміну у цей термін спостереження перевищував рівень тварин без змодельованої патології у 4 рази і був на 24,7 \% меншим, ніж у травмованих тварин без корекції. Лізис азоказеїну був дещо вищим - перевищення стосовно здорових тварин склало 4,2 раза, що на 44,1 \% менше, ніж у тварин без корекції. Лізис азоколу був ще меншим - 192 \% від показника тварин без змодельованої патології і на 35,2 \% менше, ніж у травмованих тварин, яким корекція не проводилась. До 21-ї доби активність протеолітичних процесів суттєво знизилась. Показник лізису азоальбуміну перевищував аналогічний показник інтактних тварин в 1,7 раза, що на 93,6 \% менше, ніж у тварин без корекції. Лізис азоказеїну перевищував норму в 1,7 раза, азоколу - в 1,5 раза. Ці показники були меншими від аналогічних показників тварин без корекції відповідно на 89,6 та 47,9 \% (табл. 1).

Отже, застосування плазми, збагаченої тромбоцитами, сповільнює активність процесів протеолізу, що може мати суттєве значення для пришвидшення процесів регенерації м'язової тканини, ушкодженої внаслідок механічної травми.

Вміст білкових інгібіторів плазми крові також зазнавав виражених змін (табл. 2). На першу добу спостереження встановлено достовірне підвищення інгібіторного потенціалу крові тварин, яким моделювали травматичне ураження м'язів. Зокрема, концентрація $a_{2}-$ МГ збільшилася в 2,1 раза. Щодо $a_{1}$-ІП, то його концентрація теж зросла, однак дещо менше - в 1,8 раза порівняно з тваринами 
Огляди літератури, оригінальні дослідження, погляд на проблему, випадок з практики, короткі повідомлення

Таблиця 1. Динаміка показників протеолітичної активності сироватки крові щурів з м'язовою травмою та корекцією PRP $(\mathrm{M} \pm \mathrm{m})$

\begin{tabular}{|c|c|c|c|c|}
\hline \multirow{2}{*}{\multicolumn{2}{|c|}{ Група тварин }} & \multicolumn{3}{|c|}{ Показник } \\
\hline & & $\begin{array}{c}\text { лізис азоальбуміну, } \\
\text { мл }^{-1} \times \text { год }^{-1}\end{array}$ & $\begin{array}{c}\text { лізис азоказеїну, } \\
\text { мл }^{-1} \times \text { год }^{-1}\end{array}$ & $\begin{array}{l}\text { лізис азоколу, } \\
\text { мл }^{-1} \times \text { год }^{-1}\end{array}$ \\
\hline \multicolumn{2}{|c|}{ Без патології, n=12 } & $2,47 \pm 0,05$ & $2,16 \pm 0,04$ & $0,81 \pm 0,02$ \\
\hline \multirow{4}{*}{ 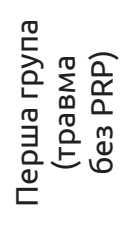 } & перша доба (n=9) & $18,74 \pm 0,21^{*}$ & $22,34 \pm 0,17^{*}$ & $6,24 \pm 0,04^{*}$ \\
\hline & сьома доба $(n=8)$ & $11,24 \pm 0,18^{*}$ & $18,22 \pm-, 15$ & $4,17 \pm 0,05^{*}$ \\
\hline & чотирнадцята доба (n=8) & $12,16 \pm 0,11^{*}$ & $13,23 \pm 0,12$ & $2,11 \pm 0,03^{*}$ \\
\hline & двадцять перша доба (n=7) & $8,17 \pm 0,10^{*}$ & $7,11 \pm 0,14^{*}$ & $1,79 \pm 0,04^{*}$ \\
\hline \multirow{4}{*}{ 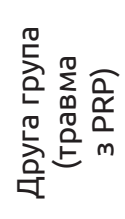 } & перша доба (n=9) & $14,36 \pm 0.11^{* \#}$ & $19,26 \pm 0,15^{* \#}$ & $4,32 \pm 0,06^{* \#}$ \\
\hline & сьома доба (n=9) & $9,54 \pm 0,08^{* \#}$ & $15,33 \pm 0.11^{* \#}$ & $2,15 \pm 0,04$ \\
\hline & чотирнадцята доба ,(n=8) & $9,75 \pm 0,09^{* \#}$ & $9,18 \pm 0,09^{* \#}$ & $1,56 \pm 0,05^{* \#}$ \\
\hline & двадцять перша доба (n=8) & $4,22 \pm 1,06^{* \#}$ & $3,75 \pm 0,07^{\star \#}$ & $1,21 \pm 0,03^{* \#}$ \\
\hline
\end{tabular}

Примітки: тут і у наступних таблицях-

1.* - зміни показників достовірні відносно інтактних тварин $(p<0,05)$;

2.\# - зміни показників тварин з корекцією достовірні відносно показників тварин без корекції на відповідні доби дослідження $(p<0,05)$.

Таблиця 2. Динаміка показників інгібіторів протеаз сироватки крові та катепсину D м'язової тканини щурів із м'язовою травмою і корекцією PRP $(\mathrm{M} \pm \mathrm{m})$

\begin{tabular}{|c|c|c|c|c|c|}
\hline \multirow{2}{*}{\multicolumn{2}{|c|}{ Група тварин }} & \multicolumn{4}{|c|}{ Показник } \\
\hline & & $\begin{array}{c}a_{1}-І П, \\
\text { мкмоль/л }\end{array}$ & $\begin{array}{l}\mathrm{a}_{2}-\mathrm{M \Gamma}, \\
\text { Г/л }\end{array}$ & $\begin{array}{c}\text { індекс } \\
\text { протеолізу }\end{array}$ & $\begin{array}{c}\text { катепсин D, } \\
\text { нмоль тирозину/ } \\
(\text { мг 6-ка × хв) }\end{array}$ \\
\hline \multicolumn{2}{|c|}{ Інтактні, n=12 } & $41,33 \pm 2,28$ & $2,38 \pm 0,05$ & $0,124 \pm 0,006$ & $3,87 \pm 0,08$ \\
\hline \multirow{4}{*}{ 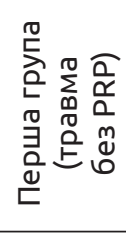 } & перша доба (n=9) & $86,75 \pm 1,21^{*}$ & $4,32 \pm 0,11^{*}$ & $0,521 \pm 0.011$ & $14,43 \pm 0,16^{*}$ \\
\hline & сьома доба $(\mathrm{n}=8)$ & $51,32 \pm 1,16$ & $3,96 \pm 0,09$ & $0,608 \pm 0,014$ & $8,31 \pm 0,14$ \\
\hline & чотирнадцята доба (n=8) & $46,42 \pm 1,07^{*}$ & $3,18 \pm 0,07^{\star}$ & $0,557 \pm 0,012$ & $6,75 \pm 0,10$ \\
\hline & двадцять перша доба $(n=7)$ & $39,27 \pm 1,13^{*}$ & $2,37 \pm 0,08^{*}$ & $0,324 \pm 0,009^{*}$ & $4,82 \pm 0,12^{*}$ \\
\hline \multirow{4}{*}{ 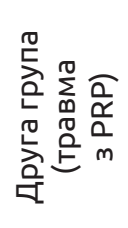 } & перша доба (n=9) & $66,25 \pm 1,41^{\text {*\# }}$ & $3,83 \pm 0,07^{\text {*\# }}$ & $0,541 \pm 0,011^{* \#}$ & $9,76 \pm 0,14^{* \#}$ \\
\hline & сьома доба $(n=9)$ & $55,24 \pm 1,56^{* \#}$ & $3,38 \pm 0,05^{\text {*\# }}$ & $0,461 \pm 0,014^{* \#}$ & $7,37 \pm 0,11^{\text {*\# }}$ \\
\hline & чотирнадцята доба (n=8) & $52,73 \pm 1,23^{* \#}$ & $3,35 \pm 0,06^{\star \#}$ & $0,365 \pm 0,012^{* \#}$ & $4,55 \pm 0,09^{* \#}$ \\
\hline & двадцять перша доба (n=8) & $40,23 \pm 1,07^{\star \#}$ & $2,84 \pm 0,07^{* \#}$ & $0,213 \pm 0,011^{* \#}$ & $4,43 \pm 0,07^{\star \#}$ \\
\hline
\end{tabular}

без змодельованої патології. Виразне збільшення вмісту $\mathrm{a}_{2}$-МГ може бути зумовлене його підвищеною продукцією паралельно з гіперпродукцією інших гострофазових білків у відповідь на дію травматичного чинника. Крім того, підвищення активності основних білкових інгібіторів можна розцінювати як неспецифічну захисну реакцію організму на посилений протеоліз та запуск фізіологічних процесів адаптації у відповідь на підвищення протеолітичної активності крові. Менш виразне зростання інгібіторного потенціалу, поряд із суттєвим зростання протеолітичної активності, ві- добразилося на значенні індексу протеолізу - він зріс у 4,2 раза. На сьому добу концентрація $a_{1}-1 П$ перевищувала рівень тварин без патології на $24,2 \%$, а а - -МГ - на 66,4 \%. Однак, зважаючи на зростання у цей період протеолітичної активності крові, індекс протеолізу зріс і був вищим у 4,9 раза від показника інтактних тварин. На 14-у добу від моменту нанесення механічної травми м'язів вміст білкових інгібіторів у сироватці крові суттєво зменшився. Концентрація а,-ІП склала 112,3 \% відносно тварин без патології, а $a_{2}$-МГ - 133,6 \%, що вказує на виснаження антипротеазних резервів 
Огляди літератури, оригінальні дослідження, погляд на проблему, випадок з практики, короткі повідомлення крові. Це $\epsilon$ одним із чинників, що не дозволяють нормалізувати активність процесів протеолізу на тлі високої активності протеолітичних ензимів, на що вказує достовірне зростання ІП у 4,5 раза. До 21-ї доби показники інгібіторів протеаз і надалі знижувались - концентрція $a_{1}$-ІП була меншою, ніж в інтактних тварин (95,0%), а а а -МГ перебувала на рівні тварин без травми. Однак нормалізація концентрації антипротеаз не корелювала з активністю протеолітичних ензимів, тому індекс протеолізу все ж був достовірно вищим, ніж у нормі, і склав $261,3 \%$.

Застосування коригуючого чинника супроводжувалось суттєвим зсувом співвідношення протеази/інгібітори протеаз у бік переважання процесів інгібування протеолізу. Вже на першу добу спостереження вміст обох ключових інгібіторів протеолізу достовірно знижувався як стосовно тварин без змодельованої патології, так тварин, яким корекцію не проводили. Зокрема, концентрація $a_{1}$-ІП склала 160,3 \%, а $a_{2}-$ МГ - 160,9 \% від рівня інтактних тварин, достовірно відрізняючись від аналогічних показників тварин із травмою без корекції в 1,3 та 1,2 раза відповідно. Однак, на тлі зростання протеолітичних процесів у цей термін спостереження спостерігалось навіть більш виразне зростання ІП - в 4,3 раза, порівняно з інтактними тваринами, і на 4 \% - порівняно з тваринами без корекції. На 7-му добу ми відмітили подальше зниження інгібіторної активності сироватки крові, порівняно з попереднім терміном. Концентрація $a_{1}$-ІП склала 133,6 \%, а а тварин без змодельованої патології, водночас відрізняючись від аналогічних показників тварин без корекції у 2,2 і 2,3 раза відповідно. Однак індекс протеолізу був значно меншим, ніж у групі тварин без корекції - на 31,9 \%, хоча в 3,7 раза перевищував рівень інтактних. На 14-ту добу інгібіторний потенціал крові знижувався повільніше, ніж фактори протеолізу, що призвело до більш суттєвого зниження інгібіторного потенціалу крові, порівняно з тваринами без застосування коригуючого чинника. Індекс хоча і перевищував аналогічний показник інтактних тварин у 2,9 раза, проте був меншим від показника тварин без ко-

рекції в 1,5 раза. Концентрація $a_{1}$-ІП при цьому склала 127,6 \%, а а - -МГ - 140,7 \% від рівня інтактних тварин. На 21-шу добу експерименту концентрація $\mathrm{a}_{1}$-ІП досягла рівня інтактних тварин, а $a_{2}$-МГ перевищувала її на 19,3 \%. При цьому індекс протеолізу також суттєво знизився і склав 171,8 \% відносно інтактних тварин, що на 52,1\% менше, ніж у групі, якій корекцію не проводили (табл. 2).

Дослідження загальної активності маркерного ферменту лізосомального матриксу катепсину D показало, що моделювання механічної травми м'язів призвело до достовірного зростання загальної активності катепсину D на першу добу експерименту у 3,7 раза з подальшим її зниженням у наступні терміни спостереження відносно тварин без змодельованої патології, що вказує на стабілізацію лізосомальних мембран у динаміці патологічного процесу. До 21-ї доби показник перевищував рівень інтактних тварин на 24,5 \%. У тварин, яким на тлі змодельованої травми проводили корекцію, спостерігали більш помірне зростання активності катепсину D на усіх етапах розвитку патологічного процесу, порівняно з групою тварин, яким корекцію не проводили. Зокрема, на першу добу від моменту моделювання травми і уведення плазми, збагаченої трмбоцитами, ензимна активність зросла у 2,5 раза, що достовірно менше, ніж у групі без корекції. Уже до 14-ї доби показник відрізнявся від норми лише на 17,5 \% і також був достовірно меншим, ніж у групі без корекції. На 21-шу добу активність катепсину D достовірно не відрізнялась від аналогічного показника інтактних тварин і тварин без корекції (табл. 2).

Висновок. У тварин з механічною травмою м'язів стегна спостерігається інтенсивне зростання протеолітичної активності крові на тлі менш виразного зростання антипротеазної активності, а також зростання проникності лізосомальних мембран. Це призводить до значного дисбалансу в системі протеази/антипротеази і зростання індексу протеолізу. Застосування плазми, збагаченої тромбоцитами, зменшує цей дисбаланс, що супроводжується зниженням індексу протеолізу, особливо у більш пізні терміни після нанесення травми.

\section{ЛІТЕРАТУРА}

1. Стан системи протеїнази/інгібітори протеїназ у щурів у динаміці іммобілізаційного стресу на тлі гіпотиреозу / О. Є. Любович, І. М. Кліщ, А. С. Вольська, Х. І. Курило // Медична та клінічна хімія. - 2018. - Т. 20, № 3. С. $110-118$.

2. Веремеенко К. Н. Протеолиз в норме и при патологии / К. Н. Веремеенко, О. П. Голобородько, А. И. Кизим. -К. : Здоров' я, 1988. - 200 с.

3. Дедуль М. И. Система протеолиза в сыворотке крови и перитонеальной жидкости при хирургическом 
Огляди літератури, оригінальні дослідження, погляд на проблему, випадок з практики, короткі повідомлення лечении больных эндометриозом / М. И. Дедуль, Л. Е. Радецкая, Л. Н. Кирпиченок // Новости хирургии. - 2006. Т. 14, № 3. - С. 74-80.

4. Зорин Н. А. Универсальный регулятор - $\mathrm{a}_{2}$-макроглобулин / Н. А. Зорин, В. Н. Зорина, Р. М. Зорина, В. Г. Левченко // Клиническая лабораторная диагностика. - 2004. - № 11. - С. 18-21.

5. Криницька І. Я. Стан протеїназо-інгібіторної системи крові та бронхоальвеолярного змиву у щурів з модельованим гепатопульмональним синдромом / І. Я. Криницька // Загальна патологія та патологічна фізіологія. - 2012. - Т. 7, № 4. - С. 92-97.

6. Атаман В. О. Патофізіологія Том 2. Патофізіологія органів і систем / В. О. Атаман. - Вінниця: ПП «Нова Книга", 2017. - С. 89-91.

7. Кресюн В. Й. Особливості зрушень стану протеїназно-інгібіторноїсистеми заумов розвитку експериментального алергічного альвеоліту і шляхи його корекції / В. Й. Кресюн, Н. Г. Семенців, М. С. Регеда // Одеський медичний журнал. - 2009. - № 3 (113). - С. 35-37.

8. Карягина И. Ю.Использование метода комплексного определения активности трипсиноподобных протеиназ, а -антитрипсина и а -макроглобулина в гастроэнтерологической клинике / И. Ю. Карягина, Р. А. Зарембский,М.Д.Балябина//Лабораторноедело.-1990.№ 2. - С. 10-13.

9. Подунай Ю. А. Возрастная динамика активности катепсинов и содержания среднемолекулярных пептидов в мышцах морского ерша / Ю. А. Подунай, И. Н. Залевская, И. И. Руднева // Ученые записки Таврического национального университета им. В. И. Вернадского. Серия «Биология, химия». - 2009. - Т. 22 (61). - № 4. - С. 128-134.

\section{REFERENCES}

1. Lyubovych, O.E., Klishch, I.M., Volska, A.S., \& Kurilo, Kh.l. (2018). Stan systemy proteinazy/inhibitory proteinaz u shchuriv u dynamitsi immobilizatsiinoho stresu na tli hipotyreozu [The state of the proteinase system/proteinase inhibitors in rats in the dynamics of immobilization stress on the background of hypothyroidism]. Medychna ta klinichna khimiia - Med. Clin. Chem., 20, 3, 110-118 [in Ukrainian].

2. Veremeenko, K.N., Holoborodko, O.P., \& Kyzym, A.I. (1988). Proteoliz v normi ta pry patolohii [Proteolysis in norm and in pathology]. Kyiv: Zdorovia [in Ukrainian].

3. Dedul, M.I., Radetskaya, L.E., \& Kyrpychenok, L.N. (2006). Systema proteolizu v syrovattsi krovi ta perytonealnoi ridyny pry khirurhichnomu likuvanni bolovykh endometriozom [Proteolysis system in blood serum and peritoneal fluid during surgical treatment of patients with endometriosis]. Novosti khirurhii - Surgery News, 14, 3, 7480 [in Russian].

4. Zoryn, N.A., Zoryna, V.N., Zoryna, R.M., \& Levchenko, V.H. (2004). Universalnyi rehuliator - $a_{2}$-makrohlobulin [Universal regulator - $\mathrm{a}_{2}$-macroglobulin]. Klinichna laboratorna diahnostyka - Clinical Laboratory Diagnostics, 11, 1821 [in Russian].

5. Krynytska, I.Ya. (2012). Stan proteinazo-inhibitornoi systemy krovi ta bronkhoalveoliarnoho zmyvannia u shchuriv z modeliuiuchym hepatopulmonalnym syndro-

mom [The state of the proteinase-inhibitory system of the blood and bronchoalveolar lavage in rats with simulated hepatopulmonary syndrome]. Zahalna patolohiia ta patolohichna fiziolohiia - General Pathology and Pathological Physiology, 7, 4, 92-97 [in Ukrainian].

6. Ataman, V.O. (2017). Patofiziolohiia Tom 2. Patofiziolohiia orhaniv i system [Pathophysiology. Volume 2. Pathophysiology of organs and systems]. Vinnytsia: PE "Nova Knyha" [in Ukrainian].

7. Kresyun, V.Y., Sementsiv, N.H., \& Reheda, M.S. (2009). Osoblyvosti zrushennia stanu proteinazno-inhibitornoi systemy za umov rozvytku eksperymentalnoho alerhichnoho alveolitu ta shliakhiv yoho korektsii [Peculiarities of changes in the state of proteinase-inhibitory system under conditions of development of experimental allergic alveolitis and ways of its correction]. Odeskyi medychnyi zhurnal - Odesa Medical Journal, 3 (113), 35-37 [in Ukrainian].

8. Karyahyna, I.Yu., Zarembskyy, R.A., \& Balyabyna, M.D. (1990). Ispolzovaniye metoda kompleksnogo opredeleniya aktivnosti tripsinopodobnykh proteinaz, $a_{1}$-antitripsina i $a_{2}$-makroglobulina v gastroenterologicheskoy klinike [Using the method of complex determination of the activity of trypsin-like proteinases, a1-antitrypsin and a2-macroglobulin in a gastroenterological clinic]. Laboratornoye delo Laboratory Matter, 2, 10-13 [in Russian]. 
Огляди літератури, оригінальні дослідження, погляд на проблему, випадок з практики, короткі повідомлення

9. Podunay, Yu.A., Zalevskaya, I.N., \& Rudneva, I.I. (2009). Vozrastnaya dinamika aktivnosti katepsinov i soderzhaniya srednemolekulyarnykh peptidov v myshtsakh morskogo yersha [Age-related dynamics of cathepsin activity and the content of medium-molecular peptides in the muscles of the sea ruff]. Uchenyye zapiski Tavricheskogo natsionalnogo universiteta im. V.I. Vernadskogo. Seriya "Biologiya, khimiya" - Scientific Notes of the Tavricheskiy National University named after V.I. Vernadsky. Series "Biology, Chemistry", 22 (61), 4, 128-134 [in Russian].

10. Pakhomov, R.I., Gasiy, G.M., Belous, I.O., \& Lavrut, T.V. (2015). Analiz, prohnozuvannia ta profilaktyka travmatyzmu z vazhkymy naslidkamy [Analysis, forecasting and prevention of injuries with severe consequences]. Zbirnyk naukovykh prats Kharkivskoho universytetu Povitrianykh Syl - Collection of Scientific Works of Kharkiv University of the Air Force, 2 (43), 139-144 [in Russian].

11. Aller, M., Arias, J., Alonso-poza, A., \& Arias, J. (2010). A review of metabolic staging in severely injured patients. Scand. J. Trauma. Resusc. Emerg. Med., 18, 27. DOI: 10.1186/1757-7241-18-27.

12. Kobeliatsky, Yu.Yu., Yovenko, I.A., Tsarev, A.B., Kuzmova, E.A., \& Perederiy, M.N. (2013). Intensivnaya terapiya politravmy $s$ pozitsiy sovremennykh mezhdunarodnykh rekomendatsiy [Intensive therapy of polytrauma from the standpoint of modern international recommendations]. Meditsina neotlozhnykh sostoyaniy - Emergency Medicine, 7, 9-14 [in Russian].

13. Ryndenko V.G., Zaitsev A.E., \& Boyko V.V. (2000). Sostoyaniye okazaniya pomoshchi postradavshim s politravmoy [The state of assistance to victims of polytrauma]. Sbornik nauchnykh trudov KhGKBSNP - Collection of Scientific Works HGKBSNP. Kharkov: Osnova [in Russian].

14. (2007). Smertnist naselennia Ukrainy u trudoaktyvnomu vitsi (monohrafiia) [Mortality of the population of Ukraine in working age (monograph).] Libanov, E.M. (Ed.). Kyiv: Institute of Demography and Social Research of the National Academy of Sciences of Ukraine [in Ukrainian].

15. (2010). Directive 2010/63/EU of the European Parliament and of the Council of 22 September 2010 on the protection of animals used for scientific purposes. Official J. Eur. Union., 276, 33-79.

16. (2011). Guide for the care and use of laboratory animals. 8th ed. Washington: The National Academies Press.

17. Kozhemyakin, Y.M. (2002). Naukovo-praktychni rekomendatsii z utrymannia laboratornykh tvaryn ta roboty $z$ nymy [Scientific and practical recommendations for keeping laboratory animals and working with them]. Kyiv [in Ukrainian].

\title{
ВЛИЯНИЕ ОБОГАЩЕННОЙ ТРОМБОЦИТАМИ ПЛАЗМЫ КРОВИ НА СОСТОЯНИЕ СИСТЕМЫ ПРОТЕИНАЗЫ / ИНГИБИТОРЫ ПРОТЕИНАЗ ПРИ ТРАВМАТИЧЕСКОМ ПОРАЖЕНИИ МЫШЦ
}

\author{
ОВ. Г. Дживак, И. Н. Клищ
}

Тернопольский национальный медицинский университет имени И. Я. Горбачевского МОз Украины

РЕзюМЕ. Нарушения протеиназо-ингибиторной системы играют важную роль в патогенезе многих патологических процессов. Чрезмерный протеолиз может привести к развитию целого ряда патологических состояний, сопровождающихся возникновением деструктивных, воспалительных и иммунных реакций.

Цель - установить особенности функционирования системы протеиназы/ингибиторы протеиназ в условиях травматического поражения мышц в эксперименте и выяснить влияние обогащенной тромбоцитами плазмы крови на состояние протеазно/антипротеазной активности.

Материал и методы. Травму мышц бедра моделировали согласно разработанной методике в условиях тиопентал-натриевого обезболивания. Опытные животные были поделены на три группы: I - контроль (без смоделированной патологии), II - животные с травматическим поражением мышц бедра без введения обогащенной тромбоцитами плазмы крови, III - животные с травматическим поражением мышц бедра и введением обогащенной тромбоцитами плазмы крови. Приготовление PRP происходило двухэтапно. Было проанализировано влияние коррекции обогащенной тромбоцитами плазмы крови на изменения протеолитических свойств и антипротеолитической активности крови в эксперименте при травматическом поражении мышц животных, которым проводилась коррекция обогащенной тромбоцитами плазмой крови. Забор биологического материала проводили на 1-е, 7-е, 14-е, 21-е сутки после травматического поражения мышц. Для исследования активности протеиназной системы и содержания ингибиторов протеолиза использованы спектрофотометрические методики.

Результаты. Исследовано влияние обогащенной тромбоцитами плазмы крови (PRP) на показатели протеиназ-ингибиторной системы крови. У животных с мышечной травмой установлено повышение протеолитической активности крови на фоне незначительного роста содержания $a_{1}$-ингибитора протеаз и $a_{2}$-макроглобулина, что указывает на недостаточное усиление антипротеолитичного потенциала для сдерживания развития деструкции. У животных, которым после нанесения травмы вводили PRP, имеет место достоверный рост протеолитической активности крови на фоне более отчетливого увеличения антипротеазной активности. Это приводит к снижению индекса протеолиза.

Вывод. При механической травме мышц наблюдается интенсивный рост протеолитической активности крови на фоне незначительного повышения антипротеазной активности. Применение РRP как средства коррекции сопровождается ростом антипротеазной активности и снижением индекса протеолиза.

КЛЮчЕВЫЕ СЛОВА: механическая травма мышц; плазма, обогащенная тромбоцитами; протеиназ-ингибиторная система. 
Огляди літератури, оригінальні дослідження, погляд на проблему, випадок з практики, короткі повідомлення

\section{INFLUENCE OF PLATELET-RICH BLOOD PLASMA ON THE STATE OF THE PROTEINASE SYSTEM/PROTEINASE INHIBITORS IN TRAUMATIC MUSCLE INJURY}

\section{Horbachevsky Ternopil National Medical University}

SUMMARY. Disorders of the proteinase-inhibitory system play an important role in the pathogenesis of many pathological processes. Excessive proteolysis can lead to the development of a number of pathological conditions that are accompanied by destructive, inflammatory and immune reactions.

The aim of the study - to establish the features of the functioning of the proteinase/inhibitors proteinase system under conditions of traumatic muscle injury in the experiment and to find out the effect of platelet-rich blood plasma on the state of protease/antiprotease activity.

Material and Methods. Thigh muscle injury was modeled according to the developed technique under conditions of thiopental sodium anesthesia. Experimental animals were divided into three groups: I - control (without simulated pathology), II - animals with traumatic injury to the thigh muscles without the introduction of platelet-rich blood plasma, III - animals with traumatic injury to the thigh muscles and the administration of platelet-rich blood plasma. The preparation of PRP took place in two stages. The effect of correction of platelet-rich blood plasma on changes in proteolytic properties and antiproteolytic activity of blood in an experiment with traumatic muscle injury, which was corrected with platelet-rich blood plasma, was analyzed. The sampling of biological material was carried out on the 1st, 7th, 14th, 21st days after the traumatic muscle injury. Spectrophotometric techniques were used to study the activity of the proteinase system and the content of proteolysis inhibitors.

Results and Discussion. Platelet-rich blood plasma (PRP) was studied for indicators of the proteinase-inhibitory system of the blood. In animals with muscular trauma, an increase in the proteolytic activity of the blood was observed against the background of a slight increase in the content of $a_{1}$-protease inhibitor and $a_{2}$-macroglobulin, which indicates an insufficient increase in antiproteolytic potential to inhibit the development of destruction. In animals that were injected with PRP after injury, there is a significant increase in proteolytic activity of the blood against the background of a more pronounced increase in antiprotease activity. This leads to a decrease in the proteolysis index.

Conclusions. With mechanical muscle injury, an intensive increase in the proteolytic activity of the blood is observed against the background of a slight increase in antiprotease activity. The use of PRP as a means of correction is accompanied by an increase in antiprotease activity and a decrease in the proteolysis index.

KEY WORDS: mechanical muscle injury; platelet-rich plasma; proteinase inhibitory system. 